\title{
John Ruskin, the medieval ordines, and meritorious suffering
}

Article

Published Version

Kaeuper, R. W. (2014) John Ruskin, the medieval ordines, and meritorious suffering. Reading Medieval Studies, XL. pp. 176191. ISSN 0950-3129 Available at

https://centaur.reading.ac.uk/84587/

It is advisable to refer to the publisher's version if you intend to cite from the work. See Guidance on citing.

Publisher: University of Reading

All outputs in CentAUR are protected by Intellectual Property Rights law, including copyright law. Copyright and IPR is retained by the creators or other copyright holders. Terms and conditions for use of this material are defined in the End User Agreement.

\section{www.reading.ac.uk/centaur}

\section{CentAUR}

Central Archive at the University of Reading

Reading's research outputs online 


\title{
John Ruskin, the Medieval Ordines, and Meritorious Suffering
}

\author{
Richard W. Kaeuper \\ University of Rochester
}

Ardent admiration for all things medieval among the eminent Victorians constitutes a wellknown phenomenon of our cultural past. Evidence of this deep appreciation, often coupled with a desire for emulation, appears prominently in nineteenth-century art and architecture, in imaginative literature, and in the remarkably voluminous corpus of scholarship on medieval subjects that the Victorians produced. To a sometimes surprising degree, modern historians still live within the orbs of light and shade created by this fascination of the nineteenth century for the Middle Ages and perhaps for the twelfth and thirteenth centuries in particular. Sometimes the legacy is happily acknowledged by modern scholars as when, to take only one example, a basic text of a medieval chronicle edited by William Stubbs or one of his eminent colleagues associated with the famous 'Rolls Series' is cited with confidence as well as gratitude. At other times modern scholars hurry determinedly away from the nineteenth-century legacy, usually in complete disagreement with its views, but perhaps sometimes merely in fear that the dread epithet 'Victorian' might stain their own interpretations and diminish their standing in the academy.

Over the decades, investigating medieval law and justice (often in collaboration with Paul Hyams at the International Medieval Congresses at Western Michigan University) and then studying chivalry through various enterprises of books, articles and conferences, has made me keenly aware of the great debt owed to our Victorian predecessors. It has also shown me the periodic necessity to chisel through Victorian encrustations in order to reach genuinely medieval attitudes and institutions. The study of chivalry as the defining code of one of the medieval ordines (those socio-professional groups originating in the divine plan for human society) provides an important case in point. Were that thick enclosing shell of Victorian interpretation left intact, the medieval warrior code of chivalry would continue to resemble a public school ethos that the elite might graciously extend downwards throughout the social pyramid to solve the seemingly eternal problems caused by overflowing male vigor.

\section{Reading Ruskin's Unto This Last}

Yet my goal in this small essay moves in a quite different direction: I wish to acknowledge and build upon a remarkable Victorian insight that can usefully inform not only understanding of chivalry, but of the medieval social orders in general. This insight appears in a pivotal work of that complex Victorian giant John Ruskin. We all recognize Ruskin as an accomplished artist, as the father of modern study of art history, and as a truly trenchant social critic. Likewise we acknowledge his fascination and infatuation with the Middle Ages. My modest claim here is that in one particular dimension, not always 
recognized, Ruskin's analysis can prove fruitful for modern medievalists; for in discussing characteristics of true professions in his own era Ruskin points us to formative characteristics of the medieval ordines in the process clarifying the role and relationship of the first two ordines, those of the clerics and knights, as well as their formal distance from the mere merchants, unsteadily situated within the third ordo, that of workers.

Perhaps it is no surprise that he produced insightful views about medieval society. His neo-medieval sensibilities in general readily appear, as, for example in his support of the pre-Rephaelite painters. Ruskin's own political and social constitution also seems relevant; since his own lifetime observers have commented on his truly remarkable combination of radicalism and conservatism, his compound of the Tory and the socialist. Though he suggests that mercantile and industrial enterprise should in ideal form be incorporated into a framework of public good, his fundamental critique remains more robust than any hopes expressed. Unstoppable as his commitment to social justice remained, however, he firmly believed in a society ordered as a hierarchy of cooperative status groups: each must be characterized by a merited sense of self-worth embodied in doing good and disciplined work, and each must show proper deference within the established social order. Only thus could the great goal of common good be achieved. His ideal Victorian society was not far from the medieval ideal society of ordines.

Achieving such goals in mid-nineteenth century England would, however, require significant changes in conceptions of wealth, and in relations between laborers and employers; it would mean serious consideration of social affection rather than any primary stress on constant, self-interested competition at the expense of others - neighbors, employees, or servants. Certainly his ideal would shun any views that reduced humans to merely greedy animals. His mixture of standards, could they have been enacted, puts one in mind of the lapidary phrase W. L. Warren used to characterize Henry II, 'a conservative who made a revolution'.

By stating even such a mixed set of views in the mid-Victorian world of commercial and industrial capitalism, Ruskin certainly provoked denunciations for his radicalism. When in 1860 he published a series of articles in The Cornhill Magazine, under the title 'Unto this Last', furious outcries of protest showed that he had drawn blood. ${ }^{2}$ Undaunted,

1 W. L. Warren, Henry II (Berkeley: University of California Press, 1973), p. 380.

2 The Cornhill Magazine i-ii (June-December, 1860), pp. 155-564. The line quoted in the title appears in Matthew xx.14. 
in 1862 he published the essays as a small separate book, with the same title. ${ }^{3}$ Despite its obscurity, the title recalls the parable of the laborers in the vineyard in the New Testament and underscores Ruskin's lifelong concern for social justice. At his funeral in 1900 a pall bearing that same title as a motto would be prominently draped across his coffin. ${ }^{4}$ The broad thrust of his attack on contemporary theories of 'political economy' and on the social and cultural consequences of commercial and industrial capitalism slowly reached and influenced many readers, among them Tolstoy, the leaders of the early British Labour party, and the young Gandhi, who translated Ruskin's book into the Gujarati language.

Passages of particular interest to medievalists appear near the end of the first of his four essays. Ruskin asks the reason for 'the general lowness of estimate in which the profession of commerce is held, as compared with that of arms'. 'Philosophically', he muses,

it does not, at first sight, appear reasonable (many writers have endeavoured to prove it unreasonable) that a peaceable and rational person, whose trade is buying and selling, should be held in less honour than an unpeaceable and often irrational person, whose trade is slaying. Nevertheless, the consent of mankind has always, in spite of the philosophers, given precedence to the soldier.

Giving force to his own inquiry, he adds, unsparingly, 'And this is right'. ${ }^{6}$

Moreover, his formal puzzlement as to the differential status accorded men of arms and men of commerce and industry was no merely rhetorical question, for he supplied reasons for arriving at his own answer. Straightforwardly he states that the worthiness of soldiers appears in their being willing and capable of self-sacrifice; merchants do not exhibit this basic trait. He strengthens his case by arguing further that 'the soldier's trade, verily and essentially, is not slaying, but being slain'? Despite all faults of recklessness,

3 'Unto this Last': Four Essays on the First Principles of Political Economy (London: Smith, Elder \&Co., 1862). Ruskin announced that despite the essays having been 'reproached in a violent manner', he was presenting them again as 'the truest, rightest-worded, and most serviceable things that I have ever written'. (Preface, p. vi).

4 My thanks to Alan Unsworth for discovering that this pall is preserved in the Ruskin Gallery of the Ruskin Museum at Coniston, Cumbria, UK.

5 Unto this Last, p. 25.

6 Unto this Last, p. 25.

7 Unto this Last, p. 25. 
put him in a fortress breach, with all the pleasures of the world behind him, and only death and his duty in front of him, he will keep his face to the front; and he knows that this choice may be put to him at any moment, and has beforehand taken his part - virtually takes such part continually — does, in reality, die daily. ${ }^{8}$

Ruskin knows he is presenting an ideal type of military figure. The brash version of the man of arms he terms a 'bravo' who, he observes, indeed follows a trade of slaying and thus is rightly held in no more respect than the merchant. But self-sacrificing service forms the being of the ideal military figure who 'holds his life at the service of the State'?

In fact, all true professions, Ruskin declares famously and more generally, have a 'due occasion of death', a point of resolute and willing self sacrifice in the interests of standards and of the common good that will require 'voluntary loss'. In theory, five great professions are at issue: those of Soldier, Pastor, Physician, Lawyer and Merchant. Each of the first four would suffer death rather than abandon ideal standards associated with their profession: defense, true instruction, healing, or ensuring justice in the nation. But of the merchant he pointedly asks, "what is his "due occasion" of death?"10 This question is indeed rhetorical: he leaves it hanging like a noose dangling from a gallows at the end of his paragraph with its list of ideal professions.

From Ruskin's Analysis into the Middle Ages

This emphasis on true professions and especially on the military and clerical orders in contrast to the merchants highlights Ruskin's essentially medieval views on so basic a topic. By stressing self-sacrifice and suffering - even, finally, the willingness to die Ruskin reproduced a key element in the valorization of the two elite medieval ordines, and reproduced as well the formal medieval distrust of the merchants who could claim nothing of the sort and who thus stood beyond glowing valorization in formulations of the divine plan." Meritorious suffering, in short, constitutes a key insight informing Ruskin's analysis. It is a sharply-etched Victorian insight worth pursuing in our effort to understand the society of the Middle Ages.

Unto this Last, p. 26.

9 Unto this Last, p. 25.

10 Unto this Last, p. 32.

11 Examples are provided in Richard W. Kaeuper, Chivalry and Violence in Medieval Europe (Oxford: OUP, 1999), pp. 134-5. It should be noted, however, that the willingness for death comes from a personal sense of completion rather than any concern for the common good. Here the medieval and the Victorian views collide. 
Formative medieval thought focused relentlessly on self-sacrifice and suffering. Suffering was sent from God and, if willingly endured by sinful humans, became redemptive. ${ }^{12}$ Such suffering was expected and appreciated by the divine Father who could only reconcile with sinful humankind because of the supreme suffering and willing sacrifice of his only Son. All knew that ceaseless human sin required constant human suffering and self-sacrifice as atoning repayment. It would necessarily be corporal suffering, for the physicality that pervaded medieval assumptions could not be gainsaid; in this world holiness inhered in saints' bones and possessions, the granting of a fief was represented by a lord handing over some material object such as a clod of dirt to his vassal; and even in the afterlife the soul was given a certain corporality so that the sinner might suffer intense if redeeming physical torments in Purgatory for years or purely punishing torments in Hell for eternity. ${ }^{13}$

Since $\sin$ inflicted a societal as well as a personal stain, certain activities, however necessary they might seem to be, would spoil the purity that was desired or even demanded by a divine power whose awesome vengeance was regularly acknowledged and indeed celebrated (if with somewhat quavering heart and voice). Purity in religion and thus stability in society was threatened by pollutants; neutralizing them constituted major social work, a process Ruskin would have understood and appreciated.

We can identify the major pollutants even without reference to recondite theory. Three human activities come readily to mind: having sex, shedding human blood, and handling money. If each activity seems necessary, or at least inevitable, each could only be viewed with deep fear and suspicion. Of course these pollutants were inseparably linked with the classic ordines, for the clerics obsessed over sexual purity in themselves and others, the knights shed blood within a dark cloud of violence, rapine and theft, and the merchants especially handled the money, such filthy lucre multiplying their sin as their profits multiplied through usury.

The required antidote to each pollutant was obviously found in strong doses of ascetic practice, willingly performed, at least by the members of the elite orders. Each ordo must ideally practice a specific compensatory and highly corporal form of asceticism, for physical suffering willingly endured in the world purged the pollutant. The process would continue to completion in the next world, but as an encouragement, suffering endured in this world was regularly noted to be meritorious without reaching the horrific levels to be

12 See the fascinating discussion in Esther Cohen, 'Towards a History of European Physical Sensibility: Pain in the Later Middle Ages', Science in Context, 8 (1995): 47-74.

13 Caroline Walker Bynum, Christian Materiality; An Essay on Religion in Late Medieval Europe (New York: Zone Books, 2011). 
anticipated in the afterworld. It would be prudent to pay some portion of the dreadful tab now, while in the world. ${ }^{14}$

As we will see - again with a nod of appreciation from Ruskin, centuries later the first order, the clerics and monks, and the second order of knighthood could carry out a practice considered fully appropriate to their vocations. What of the merchants? Although they would be the object of as much attention as their social betters, they were only suspect members within the third ordo, that of the workers. Clerical intellectuals likely much preferred to think of this third order as constituted by the massive corpus of simple and stalwart farmers, whose asceticism would be obvious to anyone observing them plowing deep soil as sleet fell. If their social function could not be doubted by anyone seated at a bountiful table, their asceticism likely seemed simply necessary, without serving as remedy for any fundamental pollutant. That demanding and socially crucial work was reserved for others. Worries about priests and warriors surely abounded, even in elite circles; but these fears seem to pale in comparison with the decided unhappiness over the merchants. As in the analysis of Ruskin, merchants lacked any meritorious asceticism to counteract the polluting exercise of their profession. Thus the link between pollutant and meritorious asceticism differs markedly from one group to another.

The case of the clerics is clearest: a physical problem involving bodies is met with an ascetic solution. Clerics dealt with polluting sexuality that so disturbed them by stressing celibacy as the detoxifying discipline of the body. It was difficult to achieve but was vigorously stressed in the wake of the ambitious late-eleventh-century Church reform. Formally required for clerics, it could be suggested for lay folk, though with little expectation of success. ${ }^{15}$ The obsessive insistence on sexual purity as a form of discipline and meritorious sacrifice, evident from so many twelfth-century sources, can perhaps nowhere better be appreciated than in The Jewel of the Church (Gemma Ecclesiastica) by that most prolific and popular writer of the age, Gerald of Wales ${ }^{16}{ }^{16}$ His book, as he tells us with characteristic modesty, was much appreciated by no less an ecclesiastical authority than Pope Innocent III. Gerald sounds the theme of celibacy tirelessly and, significantly discusses the struggle in military and highly ascetic language.

14 Sermon exempla often make the point: see BL, Royal MSS, 7DI, fol. 138; BL, Additional MSS, 159, fol. 6b; BL, Royal MSS, 12E I, fol. 159. Duke Henry of Lancaster in 'Le livre de seyntz medecines' suggested that this represents 'a bargain' (une bonne marchandise). For this view and other instances of such sentiments, see Richard W. Kaeuper, Holy Warriors: The Religious Ideology of Chivalry (Philadelphia: University of Pennsylvania Press, 2009), pp. 40, 236.

15 André Vauchez discusses cases of voluntary lay chastity in the thirteenth century in The Laity in the Middle Ages: Religious Beliefs and Devotional Practices, trans. by Daniel Bornstein (Notre Dame: University of Notre Dame Press, 1993), pp. 185-204.

16 Gerald of Wales, The Jewel of the Church: A Translation of 'Gemma Ecclesiastica' by Giraldus Cambrensis, trans. by John Hagen (Leiden: Lugduni Batavorum, 1979). 
Resist the desires of the flesh manfully. Dry up the springs of lust through fervor of the spirit. The greater the struggle, the greater the crown. ${ }^{17}$

He admonishes: 'Know, then, that if a man does not punish [himself], God will do so'. ${ }^{18}$ And the explicitly military terminology continues: 'No crown is given unless the struggle of a fierce battle has taken place'. ${ }^{19}$ In fact, he says, 'We ought to fight courageously against the strong desires of the flesh; we must suffer [with Christ] if we are to reign with him'. ${ }^{20}$ Monks must recognize that 'life on earth is $a$ warfare and a continuous conflict with the enemy'. ${ }^{21}$ He summarizes for his brothers the teaching of St Paul:

As Christ offered the Father His entire body as a victim for us, generously exposing Himself to pains, to spittle, to stripes, to chains, to blows, to insults, and finally to the ignominious gibbet of the cross, so we should crucify our bodies to the world for His sake and willingly exposing ourselves to abstinences and insults and persecutions, devote our bodies completely to the service of God. $^{22}$

A few lines later Gerald approvingly quotes St Jerome, 'You are effeminate soldiers if you desire to be crowned without a struggle, for no one will be crowned unless he fights manfully' ${ }^{23}$ Within the cloister, even within the priesthood, life is interpreted as a species of spiritual warfare, with celibacy as the key to salvific ascetic discipline.

So many voices echoed the refrain. 'That a priest needs to be pure', Thomas of Cobham's Summa Confessorum declares in the early thirteenth century, 'is so obvious that it hardly needs saying'. ${ }^{24}$ John Pecham in Ignorantia Sacerdotium (1281) states that although holy orders are a form of perfection, marriage is a sacrament for the imperfect. True heroic endurance, in other words, graces the celibates. ${ }^{25}$ Clearly clerics and monks were expected to give up something important and thereby gain God's favor.

17 Jewel of the Church, p. 146.

18 Jewel of the Church, p. 150.

19 Jewel of the Church, p. 153.

20 Jewel of the Church, p. 160.

21 Jewel of the Church, pp. 158-159.

22 Jewel of the Church, p. 202.

23 Jewel of the Church, p. 203.

24 Quoted in John Shinners and William Dohar, Pastors and the Care of Souls in Medieval England (Notre Dame: University of Notre Dame Press, 1998), p. 9.

25 Pastors and the Care of Souls, pp. 131-32. 
Sometimes the clerics saw themselves standing apart from all lay people, whether of chivalric or mercantile stamp. In one sense this is only an instance of the rivalry of groups often noted as an aspect of High Medieval social thought no less than a fact of social interaction. ${ }^{26}$ From a highly theoretical perspective clerics could lump knights and merchants together; certainly both groups of lay folk were troublesome and morally dangerous. One of the standard exempla appearing in numerous collections of moral tales asks the question: how many demons does it take to watch such and such a site? The answer always specifies that many are required to keep watch over a monastery, filled with a multitude of true souls whose possible slippage from grace must be prevented, but only one need watch some other site (the target of the story), since its inhabitants are already given over to the power of the devil. ${ }^{27}$ Significantly, though this targeted site may be a town gate or marketplace, it may also be a castle. Both the knights' violence and the merchant's usury — and the sexual morality of both — troubled society and offended divine order in the world.

Often when thinking of the knighthood clerics focused on revulsion from blood pollution. In his Deeds of Louis the Fat, Abbot Suger of St Denis quotes Pope Paschal II who declared that knights' hands are stained by blood from the sword. ${ }^{28}$ And in describing the coronation of his hero Louis the Fat, as King of France, Abbot Suger significantly distinguished between the merely secular sword of knighthood and the ecclesiastical sword used righteously to correct evildoers. In the coronation ceremony, he insists, Louis exchanged one sword for the other. ${ }^{29}$ Perhaps something of the loathing of blood pollution was again at work in the minds of both Suger and Gerald of Wales when (borrowing from the Roman author Lucan) they described the German Emperor and Richard Lion-Heart, respectively, as happy only when they could mark their triumphs by walking in the blood of their enemies. ${ }^{30}$ Bernard of Clairvaux, in his treatise for the Knights Templar, denounced merely worldly knighthood - the vast majority of knights, of course - as stained with murder, while the Knights Templar piously killed evil. Were the net to be spread beyond worries specifically focused on blood pollution to sweep up clerical attacks on the violence, pillage, theft, rape and arson that so often accompanied blood pollution, the catch would be

26 Caroline Walker Bynum, Jesus as Mother: Studies in the Spirituality of the High Middle Ages (Berkeley: University of California Press, 1982 ), pp. 82-109.

27 See, for example, BL, Additional MSS, 32678, fol. 80b; BL, Additional MSS, 11284, fol. 90b; BL, Egerton MSS, 1117, fol. 179b.

28 Suger. Deeds of Louis the Fat, trans. by Richard Cusimano and John Moorhead (Washington, D. C.: Catholic University of America Press, 1992), p. 50.

29 Deeds of Louis the Fat, p. 63. 
seen in the enactments of the Lateran Councils of 1139 and $1179 .{ }^{34}$ The Parisian circle of Peter the Chanter, a group of theologians especially concerned with issues of social ethics, played a particularly prominent role through preaching campaigns and through influence in ecclesiastical legislation late in the twelfth century and into the early decades of the thirteenth century. They seem to have pioneered the use of vivid sermon exempla to castigate the usurers, often showing them in full evil in life and in final confusion upon their deathbeds. ${ }^{35}$

Jacques de Vitry, a renowned preacher and member of this Parisian intellectual circle, could on the one hand include the merchants in 'the multiform types of men' who 'have special rules and institutions differing from each other according to the different types of talents entrusted to them by the Lord, so that the one body of the Church is put together under its head, Christ, out of people of differing conditions'. ${ }^{36}$ Yet he could, on the other hand, approvingly tell a story of a cleric who wanted to 'show to all how ignominious was the profession of usury, which no one would dare publicly to confess'. This cleric announced in his sermon, 'I wish to absolve you according to the trades and professions of each'. Beginning with the smiths, he then called on all the men present to rise craft by craft; but when he asked for the usurers to rise to receive absolution, for shame no one dared stand up, 'but all hid themselves for shame, and were derided, and put to confusion by the others for not daring to confess their profession'. ${ }^{37}$ Another preacher, Eudes de Châteauroux, disparagingly compared the townsmen and usurers to the good knights who were taking the cross. Unlike the knights who showed their thorough trust in God, these townsmen do not want to join the movement 'and what is more they aim to deprive those who join up of their inheritance'. Yet, Eudes exults, 'the authority will always stay with the nobles, whether or not the usurers who devour them want it'. ${ }^{38}$ Caesarius of Heisterbach, in

34 John W. Baldwin, Masters, Princes, and Merchants: The Social Views of Peter the Chanter and his Circle, 2 vols (Princeton: Princeton University Press, 1970), i, pp. 296-311.

35 Etienne de Bourbon, for example, sets forth a striking contrast between the pious death of Louis IX and the death of a usurer: Anecdotes historiques, légendes, et apologues tirés du recueil inédit d'Étienne de Bourbon ... [entitled 'Tractatus de diversis materiis prcedicabilibus'] publiés ... par A. Lecoy de la Marche. Lat., ed. by Richard Albert Lecoy de la Marche (Paris: Société de l'Histoire de France, 1877), p. 63.

36 See Vitry's Sermones vulgares, 344-442 [see n. 37 below] cited in Giles Constable, Three Studies in Medieval Religious and Social Thought (New York: CUP, 1995), p. 330.

37 Jacques de Vitry, The Exempla or Illustrative Stories from the Sermones Vulgares of Jacques de Vitry, ed. by Thomas Frederick Crane (London: Pub. for the Folk-lore Society, 1890), pp. 76, 206-7.

38 Quoted in Christoph Maier, Crusade Propaganda and Ideology: Model Sermons for the Preaching of the Cross (New York: CUP, 2000), pp. 147-49. 
one of his miracle stories, tells of Gottschalk the usurer who had redeemed a crusading vow on the cheap, paying less than he should on the pretence that he was a poor man. Worse, he loudly boasted of his success later in tavern talk, and taunted 'pilgrims' who actually planned to honor their vows and go on crusade:

'You fools', he would say, 'are going to cross the sea and waste your substance, and expose your lives to all kinds of dangers, while I, for the five marks with which I redeemed my vow, shall stay at home with my wife and children, and get as good a reward as you'. ${ }^{39}$

Gottschalk is negating the very ascetic basis of crusading. Of course, Caesarius assures us, he went to hell, where he exchanged his comfortable tavern bench for unending pain in a burning chair. It is noteworthy that suffering in hell he witnesses the punishment of a noted knight who had stolen a heifer from a poor widow. The man had refused contrition and confession and had been buried in consecrated ground only after his widow had bribed the priest [I, 76-78]. In hell he is gored eternally by the stolen heifer. ${ }^{40}$ Yet the knights are usually more favored than the merchants. A Jacques de Vitry story tells of a knight who, while crossing a bridge in Paris, hears a wealthy burgher blaspheming God. He punishes the man with a terrible blow to the mouth, breaking the offender's teeth. Brought before the king of France to answer for this action, the knight says that he would be unable to bear hearing his earthly king reviled, how much more should he revenge his heavenly King. The earthly king honors and releases him and ignores the burgher's claim. ${ }^{41}$ The general attitude appears concisely in an account of social origins written into an anonymous fourteenth-century collection of religious tales and fables. God created three divisions of humanity:

The three types [genera] of people God made are the clerics, the knights, and the workers. And the fourth group, the townsmen and usurers, were thought up by the Devil. They are not clerics, because they do not know letters; they are not knights, because they do not know how to bear arms; they are not workers because they are not engaged in human labor - the devil works them! Likewise the merchants are among men like the drones among bees who do not make honey, nor carry fruit, but do harm to the bees. Similarly the merchants oppress

39 Caesarius of Heisterbach, The Dialogue on Miracles of Caesarius of Heisterbach, ed. and trans. by H. von E. Scott and C. C. Swinton Bland (London: G. Routledge, 1929), i, p. 77.

40 Dialogue on Miracles, p. 78.

41 Vitry, Exempla pp. 91, 221-22. 
the clerics, supply the knights, and shake down the workers, and because on no day do they serve, they suffer idleness and injure many. For this reason Solomon said that idleness begets all evil. ${ }^{42}$

If not good theology, this is powerfully revealing social commentary.

The final moments of a usurer's life were often negatively caricatured in sermon stories and collections of moral tales. In the throes of death they lose speech, but momentarily recover only to ask about their money. Their bodies rest uneasily in consecrated ground and may have to be moved, as heavenly warnings suggest. Exhumed, one is found to share his coffin with a disgusting toad that is busily stuffing a coin into his lifeless mouth. ${ }^{43}$ Another, whose dead body is examined, strangely has no heart; it is found, of course, resting securely in his money chest. ${ }^{44}$ The story contrasts sharply with that reporting the examination of the heart of a pious knight who had died while on crusade on the Mount of Olives, in fact: his heart was found to contain a tiny but massively significant golden crucifix. In a later version of this story his heart is even found to be quartered and bleeding; it bears a concise inscription in gold: Jesus est amor meus. ${ }^{45}$ One suspects that John Ruskin might have appreciated these harsh stories directed at greedy and self-centered materialism, incapable of self-sacrifice.

Of course social life was never so simple as formal analysis portrayed it. In fact, if the medieval church feared the dangers of both knights and merchants, it undeniably needed both; and was taking steps toward careful accommodation with chivalric and mercantile functions essential to a rapidly developing society. Over time knighthood acquired noble status and came to be tirelessly lauded, even as it was urged insistently to accept clerical direction, to act in the interests of justice at home, and to enlist on crusades (both at home and abroad). If their blood pollution troubled thoughtful minds, much of the violence in which blood was spilled had to be recognized as licit and most knights

42 BL, Harley MSS, 268, fol. 29: Tria sunt genera hominum que fecit deus: clericos, milites, et laborantes et quartus genus excogitavit diabolus, s[cilicet] burgenses et usurarios, qui non clerici quia nescierunt litteras, non sunt milites quia nesciunt arma portare, non sunt laboratores quia in labore humanum non sunt et diabolus eos laborabat. Item burgenses sunt inter hominess sicut busones inter apes qui nec mellificant nec frucaferant set apibus nocent. Similiter burgenses clericos opprimunt, milites exornant, laborantes excutiunt et quia die nullo serviunt otium tolunt et pluribus nocent. Propterea dicit salamon otiositas parit omne malum.

43 BL, Royal MSS, 7D1, fol. 129.

44 BL, Additional MSS, 27909 B, fol. 93b, col. 2.

45 BL, Harley MSS, 239, fol. 234. For a somewhat similar exemplum see BL, Additional MSS, 18364, fol. $41 b$. 
accommodated as holy warriors. ${ }^{46}$ To a lesser degree, canon lawyers found ways, however, of integrating the merchants into medieval Christian society, usury and all. Even popes enthusiastically took loans from the greatest of them, and paid them interest under one cover or another. Across Europe their gifts to churches were welcomed and accepted, whatever the disapproving sermon exempla might say. The commercial and financial takeoff of high medieval Europe was not stopped cold by measures against usury. ${ }^{47}$ But the clerics who emphasized their own asceticism could scarcely - in their abstract formulations - appreciate the merchants who had none; and they came to accept the knights whose function involved heroism and ascetic sacrifice, even though it earned them glory in this world and God's good will in the next.; but it was a harder task to find escape hatches for the usurers on the issue of redemptive suffering - indeed of being willing to suffer. Merchants were never heroic figures with a recognized discipline or voluntary selfsacrifice; and they certainly could claim no meritorious corporal suffering.

Despite all pragmatic accommodation, then, clerics hammered home the point repeatedly. An evocative miracle story in a collection of Odo of Cheriton (a thirteenthcentury writer popular long after his death) tells that on his wedding day a usurer passed beneath the portal of a church bearing a stone figure of a usurer. At just that moment the heavy stone purse clutched by the figure broke loose and in its fall struck and killed the man ${ }^{48}$ It is hard to imagine a parallel story being told of a knight killed by a stone sword falling from a military statue on a church façade. Likewise, gifts to the church from knights (however obtained) were accepted in these stories with honor and thanks, even by clerics who must have known that the source might be morally tainted (as their other writings suggest). But the oats a usurer gave to a priest in a moral tale are found to be full of serpents. ${ }^{49}$ Significantly, in another moral tale the alms of a miserly, money-hungry knight similarly turn to serpents which, in this case, are said to devour him. ${ }^{50}$ Some tales told against full-time usurers seem warnings against any clerical softness in the treatment of these sinners: one vivid tale pictures a usurer, who has endowed a church and secured a prime burial spot before the altar, rising suddenly from his grave to beat the frightened monks with a candlestick snatched from the altar; even re-burying his body outside the

Kaeuper, Holy Warriors.

47 See the seminal study by John Baldwin, 'The Medieval Merchant at the Bar of Canon Law', Papers of the Michigan Academy of Science, Arts, and Letters, 44 (1959): 287-99.

48 BL, Arundel MSS, 231, fol. 81 b. The story was also told by Etienne de Bourbon: see de la Marche, ed., Anecdotes historiques, légendes, p. 60.

49 BL, Additional MSS, 1128, fol. 3 b.

50 BL, Harley MSS, 2391, fol. 167; cf BL, Additional MSS, 18364, fol. 43b, in which a usurious knight is punished with serpents. 
churchyard secures them no peace, for the man haunts the neighborhood. Finally the monks realize that they must return his endowments, earned by foul usury. ${ }^{51}$ The wise course is suggested in one of Jacques de Vitry's sermon exempla: a usurer is refused burial even in the church cemetery by a stern parish priest. When the usurer's friends protest, the priest puts the corpse on the back of an ass and suggests the will of God be done. Straightaway the beast carries its load to the gallows where robbers are hanged and shakes it off into a dunghill under the gallows, where the priest resolutely leaves it. ${ }^{52}$

By contrast, knightly spokesmen asserted confidence in their own ordo that even their clerical cousins would not dismiss. Geoffroi de Charny - a vigorous, practising knight wrote in his major mid-fourteenth-century treatise, a knight can save himself in his profession of arms, if other great sins do not intervene. ${ }^{53}$ And he was not the first to insist on the possibilities of salvation in a knightly 'calling'. In the 1170s Etienne de Fougères, bishop of Rennes, wrote in his Livre des Manières that the knight

...can save himself in his order if nothing is found to cause him remorse. But if he wants to murder traitorously or deceitfully destroy [? pincier] or kill, then he must indeed be expelled from the order, have his sword removed, be harshly punished spurs removed and be thrown out from among the knights. ${ }^{54}$

The bishop who penned these lines looked at knights with unblinkered vision. But it is worth noting that even the disqualifying sins are violations of the true form of lay 'labor' within the order, rather than offenses drawn from an ecclesiastical catalogue.

Thus, if we think of three basic pollutants that might be remedied by the asceticism of three socio-professional groups a highly revealing pattern emerges. If the clerics suffered physically in dealing with the toxin of sexuality, they won high praise and divine approval. The merchants who ran their hands lovingly through piles of polluting coin practised no physical asceticism at all and, soundly excoriated on earth, faced an uncertain spiritual future. The knights, however, got the best of both worlds. Despite engaging in blood pollution, their suffering on arduous campaign and in hard fighting — ever in good causes, of course - won them the loot and praise that sustained their dominant position in society and bolstered their hope of yet more glory in the halls of heaven.

51 BL, Arundel MSS, 506, fol. 27, col. 2.

52 Vitry, Exempla, p. 158.

53 Kaeuper and Kennedy, Book of Chivalry, pp. 164-65.

54 Etienne de Fougeres, Le Livre des Manières, ed. by R. Anthony Lodge (Geneva: Droz, 1979), pp. 13-14. 
Though he was worrying about the effects of commercial and industrial expansion in his own age and anguished over desecration of the 'green and pleasant land' he loved, John Ruskin, ever attuned to the medieval world, reproduced in his mid-nineteenth- century writing a core set of basically medieval values. If these are worthy of scholarly note as a critique of Victorian society, they likewise illuminate medieval frameworks for society not always fully explored. Much gratitude is owed Ruskin for these insights, a splendid instance of the Victorian world understanding the medieval world. Caution must, of course, accompany gratitude. Ruskin's elite professions are given pure motives and show ultimate concern for the common good. That Ruskin naturally wished these values to guide his own Victorian society is apparent; yet as hard-headed historians we need not mistake the ideal for reality either in the medieval past he loved or the Victorian world with which he struggled throughout a troubled lifetime. As always our inheritance from the Victorians is generous, but must be accepted with great care. 